\title{
Microparticles: The good, the bad, and the ugly
}

\author{
Victor A. Ferraris, MD, PhD
}

See related article on pages $305-11$.

What are microparticles? Microparticles are part of the spectrum of extracellular vesicles that include exosomes, microparticles, and apoptotic bodies. Extracellular vesicles originate from various subcellular compartments and appear in plasma, urine, saliva, and inflammatory tissues. ${ }^{1}$ Microparticles are vesicles that are shed from cells, lack a nucleus, contain a lipid membrane, and are defined by their sizes and the expression on their surfaces of antigens specific to their cells of origin.

Most microparticles are small membrane-derived vesicles that come from activated or apoptotic platelets and to a lesser extent from red blood cells. They are released into the circulation and express antigens that allow identification, typically by specific monoclonal antibodies. They serve as biomarkers, procoagulant agents, participants in atherogenesis, and agents of transfer of biologic information. $^{2}$ They have impermeable membranes containing receptors that allow identification of the cell of origin and provide binding sites that attach to living cells. Microparticles range in size from 100 to $1000 \mathrm{~nm}$, allowing detection and specific identification by flow cytometry gated to this size range and with specific monoclonal antibody probes. The article by Jy and coauthors ${ }^{3}$ published in this issue of the Journal uses flow cytometry with specific markers for red blood cell surface antigens and for platelet surface antigens to measure microparticles in the peripheral blood of patients undergoing cardiac operations. They found surprising results.

\section{THE GOOD}

In the process of gaining more information about microparticles, paradoxic actions of these intriguing submicron structures surfaced in recent literature. Microparticles deliver growth factors, messenger RNAs, microRNAs, and even cell surface receptors to target cells. They play a

From the Department of Cardiothoracic Surgery, University of Kentucky, Lexington, Ky.

Disclosures: Dr Ferraris reports consultant work for NovoNordisk, lecture fees from Baxter Healthcare and CMEology, and service as a member of the advisory board for Haemonetics.

Received for publication Aug 18, 2014; accepted for publication Aug 20, 2014; available ahead of print Sept 26, 2014

Address for reprints: Victor A. Ferraris, MD, PhD, Department of Cardiothoracic Surgery, University of Kentucky, A301, Kentucky Clinic, 740 S Limestone, Lexington, KY 40536-0284 (E-mail: Ferraris@earthlink.net).

J Thorac Cardiovasc Surg 2015;149:312-3

$0022-5223 / \$ 36.00$

Copyright (c) 2015 by The American Association for Thoracic Surgery

http://dx.doi.org/10.1016/j.jtcvs.2014.08.051 prominent role in cell-cell communication by binding and fusing with target cell membranes or by adsorption through receptors. Their role in transferring highly functional intracellular biomolecules can influence a host of sometimes paradoxic physiologic and pathologic processes. ${ }^{4}$

The article by $\mathrm{Jy}$ and coauthors ${ }^{3}$ outlines a potentially beneficial effect of microparticles. This article is an example of "what was old is now new." Nieuwland and colleagues ${ }^{5}$ identified procoagulant microparticles in patients undergoing cardiac operations as early as 1997 . The procoagulant activity of microparticles seems to provide beneficial intrinsic and extrinsic clotting in patients after cardiopulmonary bypass. The timing of the appearance of microparticles immediately after cardiopulmonary bypass, whether fortuitous or scripted, predicts less bleeding and blood transfusion. After cardiopulmonary bypass, patients at risk for coagulopathic bleeding have a need for the procoagulant activity of microparticles, especially platelet-derived membrane fragments that contain tissue factor. There is great intuitive sense in the value of microparticles in patients at risk for bleeding. Other evidence supports this notion. After trauma, patients with coagulopathies had lower microparticle levels than did nonbleeding patients. ${ }^{6}$ A congenital deficiency in platelet microparticles predicts bleeding tendency in Castaman defect. $^{7}$ It seems that good things happen to hemostasis when microparticles are present.

\section{THE BAD}

Recent studies demonstrated that microparticles function as a transport and delivery system for bioactive molecules, participating in hemostasis and thrombosis, inflammation, malignancy and infection transfer, angiogenesis, and immunity. ${ }^{1}$ With this diversity of transport molecules, it is easy to see that microparticles may have both beneficial and detrimental actions. Further, the same property of microparticles may have opposite effects depending on the site and stimulus of activation of the parent cell. For example, survivors of myocardial infarction have increased levels of platelet microparticles, ${ }^{8}$ in contrast to the association of microparticles with improved hemostasis after cardiac operations.

One important negative impact of microparticles lies in the realm of carcinogenesis, tumor progression, and prothrombotic states associated with cancers. As such, almost every step of the metastatic process has now been linked with platelet microparticle involvement. ${ }^{9}$ The number of tissue factor-positive microparticles from tumor cells correlates with the thromboembolic rates in patients with cancer. ${ }^{10}$ Platelet inhibition prevents accumulation of cancer 
cell-derived microparticles at sites of thrombosis in animal models. ${ }^{11}$ High levels of platelet microparticles are correlated with aggressive tumors and poor clinical outcomes. Certain microparticles may be useful biomarkers predictive of long-term mortality in patients with resected lung cancer. $^{12}$ Undoubtedly, because of the multiplicity and widespread presence of microparticles in the circulation, new information will be forthcoming and patients undergoing cardiothoracic surgery will inevitably benefit from exploring these boundaries.

\section{THE UGLY}

Microparticles are ugly. They are little pieces of disrupted or destroyed cell membranes or organelles that were viewed as nonfunctioning "dust" by early investigators. New insights suggest that microparticles are far more than trash, and the article by Jy and coauthors ${ }^{3}$ points out the potential importance of microparticles as a biomarker in predicting, if not determining, the need for transfusion after cardiac procedures. The observation by these authors raises the $\$ 64$ question, do microparticles play a role in regulation of bleeding, or are they simply passive observers derived from activated cells? Results presented by Jy and coauthors $^{3}$ suggest that microparticles are active participants in the perioperative hemostatic process, although the evidence is embedded in terms such as association and based on regression analysis, rather than a cause and effect relationship. There are many unanswered questions related to microparticles. How long do they survive? What are the molecular interactions that produce the effects of microparticles? Can microparticle levels be manipulated to the patient's advantage? I am sure that these questions and more will be answered in the future, and there will be more revelations like those of Jy and coauthors. I can't wait to see how the story of these ugly little particles evolves.

\section{References}

1. Loyer X, Vion AC, Tedgui A, Boulanger CM. Microvesicles as cell-cell messengers in cardiovascular diseases. Circ Res. 2014;114:345-53.

2. Herring JM, McMichael MA, Smith SA. Microparticles in health and disease. $J$ Vet Intern Med. 2013;27:1020-33.

3. Jy W, Gomez-Marin O, Salerno TA, Panos AL, Williams D, Horstman LH, et al. Presurgical levels of circulating cell-derived microparticles are robust predictors of transfusion requirement in coronary artery bypass graft surgery. J Thorac Cardiovasc Surg. 2015;149:305-11.

4. Burnouf T, Goubran HA, Chou ML, Devos D, Radosevic M. Platelet microparticles: Detection and assessment of their paradoxical functional roles in disease and regenerative medicine. Blood Rev. 2014;28:155-66.

5. Nieuwland R, Berckmans RJ, Rotteveel-Eijkman RC, Maquelin KN, Roozendaal KJ, Jansen PG, et al. Cell-derived microparticles generated in patients during cardiopulmonary bypass are highly procoagulant. Circulation. 1997;96:3534-41.

6. Matijevic N, Wang YW, Wade CE, Holcomb JB, Cotton BA, Schreiber MA, et al. Cellular microparticle and thrombogram phenotypes in the Prospective Observational Multicenter Major Trauma Transfusion (PROMMTT) Study: correlation with coagulopathy. Thromb Res. 2014;134:652-8.

7. Italiano JE Jr, Mairuhu AT, Flaumenhaft R. Clinical relevance of microparticles from platelets and megakaryocytes. Curr Opin Hematol. 2010;17:578-84.

8. Michelsen AE, Brodin E, Brosstad F, Hansen JB. Increased level of platelet microparticles in survivors of myocardial infarction. Scand J Clin Lab Invest. 2008; 68:386-92.

9. Nash GF, Turner LF, Scully MF, Kakkar AK. Platelets and cancer. Lancet Oncol. 2002:3:425-30.

10. Han X, Guo B, Li Y, Zhu B. Tissue factor in tumor microenvironment: a systematic review. J Hematol Oncol. 2014;7:54.

11. Mezouar S, Darbousset R, Dignat-George F, Panicot-Dubois L, Dubois C. Inhibition of platelet activation prevents the P-selectin and integrin-dependent accumulation of cancer cell microparticles and reduces tumor growth and metastasis in vivo. Int J Cancer. May 29, 2014 [Epub ahead of print].

12. Wang CC, Tseng CC, Hsiao CC, Chang HC, Chang LT, Fang WF, et al. Circulating endothelial-derived activated microparticle: a useful biomarker for predicting one-year mortality in patients with advanced non-small cell lung cancer. Biomed Res Int. 2014;2014:173401. 